\title{
A Flipped Design of College English Speaking Class in the Perspective of Wisdom Teaching
}

\author{
Shuang Lv \\ General Education College \\ Heihe University \\ Heihe, China 164300
}

\begin{abstract}
Based on the wisdom teaching concept, the flipped classroom is applied to the college spoken English teaching with the help of modern communicative technology and mobile micro-learning. The design of the teaching procedures is introduced in four aspects-the preparation before the class, the demonstration and interaction in the class, the enhancement and practice after class, and the feedback. The teaching mode is specified to perfect the flipped college English speaking class and to achieve the wisdom teaching objectives. It is beneficial for the teacher to integrate the teaching materials and for the students to develop their language and skills, autonomic learning ability, self-cognition, self-discipline, cooperative ability, inquiry ability and practical ability.
\end{abstract}

Keywords-flipped classroom; wisdom teaching; college spoken English; mobile micro-learning

\section{INTRODUCTION}

The essence of education is to make the students be enlightened and inspired in the process of learning. People concentrate more on the inheritance of the knowledge under current education, neglecting its worth of cultivating students' wisdom. The teachers of college spoken English, a basic and practical course, need to revolutionize their teaching concepts, ways and methods to achieve the wisdom teaching objectives.

\section{The CURRENT SituAtion OF COLlEGE SPOKEN ENGLISH TEACHING}

\section{Classroom Teaching}

In many colleges and universities, spoken English is not paid full attention, whether its curricular structure, system or arrangement. For those of non-English majors, the college English focuses on the intensive course. Due to the large class and the inadequate facilities, the listening and speaking class always retreat to listening with less time for oral practice. Some students, with their poor English or the Chinese introvert character, don't have enough selfconfidence to speak in public or participate actively in class. Therefore, the teaching is deficient. In recent decade, researchers begin to trial the flipped classroom to improve

Sponsored by Young Scientific Research Elitists Sponsorship Program in Heihe Universtity. the spoken English teaching. They have got some achievements, but the teaching mode, materials, ways and methods have not been specified.

\section{Extracurricular Teaching}

In our country, researches on extracurricular teaching mainly fall into three aspects: the activity designs, the supervision mechanism and the learning means. Researchers believe that the extracurricular activities should be designed differently in different phases to motivate students' interests and cooperation. The supervision mainly involves the assignment files, team members' responsibilities, partnership development records, tape tracing, teaching assistant tutoring and oral tests, which play an active role in cultivating students' self-understanding, self-reflection, selfassessment and the ability of problem solving. As to the learning means, researchers study the cooperative learning and try to use the modern communicative technology to create language environment. For example, the video microblog and apps via mobile micro-learning are employed to learn spoken English online, visually and interactively. All these studies lay emphasis on self-teaching, but touches less on the wisdom teaching objectives and the specific ways to achieve them in the whole teaching process.

Foreign language teaching, with many variables, is dynamic and nonlinear. It is hard to teach the knowledge and develop skills in the limited classroom lecturing. For the sake of less class hours and high demands, college spoken English can be facilitated by modern teaching technology. The learning means and styles in the new era highlight autonomy, mobility and liberty, which call for the revolution of teaching concept, contents and methods.

\section{THE CONSILIENCE OF FLIPPED CLASSROOM AND WISDOM TEACHING}

\section{The Basic Features of the Flipped Classroom}

The flipped classroom is a mode, in which students learn the new knowledge online before class and finish their assignments offline, and the teacher gives individualized guidance and then students interact in class. It is a way to change the procedure of teaching, imparting knowledge before class and internalizing knowledge in class. [1] 
The most salient feature of flipped classroom is that students, having acquired information from online resources, attend the class with questions and tasks, and the teacher helps to solve their problems and guide them to practice in order to achieve better teaching effects. First, the roles of teachers and students are changed. The former controller and lecturer are now a guider and promoter, while the passive receiver is now an active inquirer. Second, the time for the interaction between teachers and students is ample. Since the teacher don't need to give much lecture, they can focus more on the interaction with students, solve their problems and help to understand and internalize what they learn. Third, students can understand better. As students need to watch the teaching video, consult the relevant resources and prepare well, they participate and comprehend better in class.

\section{The Basic Features of Wisdom Teaching}

Based on R.J.Sternberg's wisdom balanced theory, the wisdom teaching aims to develop students' wisdom, which regards thought communication as body and the developing process of teaching as emphasis.[2] It puts that teaching knowledge should be substituted by cultivating wisdom. Wise ways and imaginative methods should be employed to foster student's wisdom quality. Teachers are the undertakers to enlighten their wisdom.

Wisdom teaching is committed to cultivate students' innovative spirit, sense and capacity. Except learning knowledge and practicing what they learn, students should be educated to have good value of merits and emotions. It holds that teaching is a process in which teachers and students, equipped with the optimized learning materials, cooperate, communicate and inquire to finish teaching activities. [3] They learn, share and improve cooperatively in it. In a democratic, equal and relaxed atmosphere, students can be encouraged to show their personalities and individuality. Teachers are obliged to motivate students' interests and initiatives in activities.

The flipped classroom fully shows the objectives and claims of wisdom teaching with respect to the flipped teaching procedures, the role of teachers and the demands of students' abilities. Therefore, teachers can try this flipped mode in the college spoken English course, facilitated by modern teaching technology, to boost students' initiatives, knowledge integration, emotions, intelligence and abilities in and out of the class.

\section{A DESIGN OF WISDOM TEACHING IN FLIPPED COLLEGE ENGLISH SPEAKING CLASS}

Following the notion-motivated output and optimized input, a flipped wisdom teaching mode is designed to teach language knowledge, to develop speaking skills, to cultivate autonomic learning ability and wisdom visually, cooperatively and interactively. Online and offline teaching and learning facilitate each other. With the expanded teaching space and time, it helps to offer more chance for students to practice their oral English. The specified design is as following in "Table I":
TABLE I.

THE DESIGN OF WisDom TeACHING IN FLIPPED COLLEGE ENGLISH SPEAKING CLASS

\begin{tabular}{|c|c|c|c|c|}
\hline $\begin{array}{c}\text { Main } \\
\text { Procedure }\end{array}$ & $\begin{array}{l}\text { Main } \\
\text { Content }\end{array}$ & $\begin{array}{l}\text { Main } \\
\text { Means }\end{array}$ & $\begin{array}{c}\text { Teaching } \\
\text { Requirements }\end{array}$ & $\begin{array}{c}\text { Wisdom } \\
\text { Teaching } \\
\text { Objectives } \\
\end{array}$ \\
\hline \multirow{3}{*}{$\begin{array}{c}\text { Preparation } \\
\text { Before } \\
\text { Class }\end{array}$} & $\begin{array}{l}\text { Backgrou } \\
\text { nd } \\
\text { Knowled } \\
\text { ge }\end{array}$ & \multirow{2}{*}{$\begin{array}{l}\text { Micro- } \\
\text { Course \& } \\
\text { MOOC } \\
\text { Video }\end{array}$} & \multirow{2}{*}{$\begin{array}{l}\text { Learn phonetics } \\
\text { and cross- } \\
\text { cultural } \\
\text { knowledge } \\
\text { online }\end{array}$} & \multirow{2}{*}{$\begin{array}{lr}\text { To foster } & \text { students' } \\
\text { discipline } & \end{array}$} \\
\hline & $\begin{array}{l}\text { Stresses } \\
\& \\
\text { Difficulti } \\
\text { es }\end{array}$ & & & \\
\hline & $\begin{array}{l}\text { Phonetics } \\
\& \\
\text { vocabular } \\
\text { y }\end{array}$ & $\begin{array}{l}\text { Fluent } \\
\text { English } \\
\text { App }\end{array}$ & $\begin{array}{l}\text { Utter training, } \\
\text { recording, \& } \\
\text { keeping records }\end{array}$ & $\begin{array}{l}\text { To improve } \\
\text { students' } \\
\text { pronunciation, } \\
\text { fluency and the } \\
\text { ability to } \\
\text { acquire } \\
\text { knowledge }\end{array}$ \\
\hline \multirow{6}{*}{$\begin{array}{l}\text { Demonstrat } \\
\text { ion \& } \\
\text { Interaction } \\
\text { in Class }\end{array}$} & $\begin{array}{l}\text { Difficulti } \\
\text { es } \\
\text { Solving } \\
\end{array}$ & $\begin{array}{l}\text { Teacher's } \\
\text { Guidance }\end{array}$ & $\begin{array}{l}\text { Coping with the } \\
\text { problems occur } \\
\text { in self-teaching }\end{array}$ & $\begin{array}{l}\text { To cultivate } \\
\text { students' ability } \\
\text { to inquire }\end{array}$ \\
\hline & $\begin{array}{l}\text { Reading } \\
\text { Aloud }\end{array}$ & $\begin{array}{l}\text { Individua } \\
1 \text { Show }\end{array}$ & $\begin{array}{l}\text { Read aloud the } \\
\text { beautiful essays }\end{array}$ & $\begin{array}{lr}\text { To } & \text { train } \\
\text { language sense } \\
\text { and confidence }\end{array}$ \\
\hline & $\begin{array}{l}\text { Free } \\
\text { Discussio } \\
\mathrm{n} \\
\end{array}$ & \multirow{4}{*}{$\begin{array}{l}\text { Team } \\
\text { Cooperati } \\
\text { on, } \\
\text { Comment } \\
\text { \&Evaluat } \\
\text { ion form }\end{array}$} & \multirow{4}{*}{$\begin{array}{l}\text { Everyone is to } \\
\text { express their } \\
\text { opinion, and } \\
\text { team scores; } \\
\text { Students } \\
\text { evaluate each }\end{array}$} & \multirow{4}{*}{$\begin{array}{l}\text { To attract more } \\
\text { involvement, } \\
\text { improve } \\
\text { students oral } \\
\text { English and } \\
\text { foster their } \\
\text { critical thinking } \\
\text { and team } \\
\text { cooperation }\end{array}$} \\
\hline & $\begin{array}{l}\text { Team } \\
\text { Debate }\end{array}$ & & & \\
\hline & $\begin{array}{l}\text { Story } \\
\text { Telling }\end{array}$ & & & \\
\hline & $\begin{array}{l}\text { Video } \\
\text { Show } \\
\end{array}$ & & & \\
\hline \multirow{5}{*}{$\begin{array}{l}\text { Consolidati } \\
\text { on \& } \\
\text { Practice } \\
\text { after Class }\end{array}$} & $\begin{array}{l}\text { Recordin } \\
\mathrm{g}\end{array}$ & $\begin{array}{l}\text { Individua } \\
\text { lly; E- } \\
\text { files }\end{array}$ & $\begin{array}{l}\text { Read aloud the } \\
\text { beautiful essays }\end{array}$ & $\begin{array}{lr}\text { To } & \text { foster } \\
\text { students } & \text { self- } \\
\text { administration }\end{array}$ \\
\hline & $\begin{array}{l}\text { Video } \\
\text { REC }\end{array}$ & $\begin{array}{l}\text { Micro- } \\
\text { recording } \\
\text { App }\end{array}$ & $\begin{array}{l}\text { Record scene } \\
\text { conversations }\end{array}$ & $\begin{array}{l}\text { To enhance the } \\
\text { ability to act } \\
\text { and involve }\end{array}$ \\
\hline & Dubbing & $\begin{array}{l}\text { English } \\
\text { Funny } \\
\text { Dubbing, } \\
\text { Fluent } \\
\text { English } \\
\text { App } \\
\end{array}$ & $\begin{array}{l}\text { Choose material } \\
\text { freely and dub }\end{array}$ & $\begin{array}{l}\text { To strengthen } \\
\text { students' } \\
\text { pronunciation } \\
\text { and self-identify }\end{array}$ \\
\hline & $\begin{array}{l}\text { Live } \\
\text { Performa } \\
\text { nce }\end{array}$ & $\begin{array}{l}\text { Spoken } \\
\text { English } \\
\text { Situation } \\
\text { al Lab }\end{array}$ & $\begin{array}{l}\text { Decorate the } \\
\text { props and } \\
\text { design } \\
\text { Situational } \\
\text { conversations } \\
\end{array}$ & $\begin{array}{l}\text { To cultivate } \\
\text { students' ability } \\
\text { to act, design } \\
\text { and participate }\end{array}$ \\
\hline & $\begin{array}{l}\text { English } \\
\text { Songs }\end{array}$ & $\begin{array}{l}\text { Chanter } \\
\text { App }\end{array}$ & $\begin{array}{l}\text { Listen to, learn } \\
\text { and sing songs }\end{array}$ & $\begin{array}{l}\text { To nurture } \\
\text { language sense } \\
\text { and sentiment }\end{array}$ \\
\hline \multirow{3}{*}{$\begin{array}{l}\text { Teaching } \\
\text { Feedback }\end{array}$} & $\begin{array}{l}\text { Online } \\
\text { Tests }\end{array}$ & $\begin{array}{l}\text { www.pig } \\
\text { ai. org, } \\
\text { Fluent } \\
\text { English } \\
\text { App }\end{array}$ & $\begin{array}{lr}\text { Write } & \text { speech } \\
\text { draft, } & \text { correct } \\
\text { online; } & \text { oral } \\
\text { grading } & \end{array}$ & $\begin{array}{l}\text { To foster } \\
\text { students' ability } \\
\text { to inquire and } \\
\text { self-challenge }\end{array}$ \\
\hline & $\begin{array}{l}\text { Offline } \\
\text { Commun } \\
\text { ication }\end{array}$ & $\begin{array}{l}\text { QQ } \\
\text { Group }\end{array}$ & $\begin{array}{l}\text { One begins a } \\
\text { new topic each } \\
\text { day }\end{array}$ & $\begin{array}{l}\text { To practice the } \\
\text { new knowledge } \\
\text { and vocabulary }\end{array}$ \\
\hline & $\begin{array}{l}\text { Electroni } \\
\text { c Files }\end{array}$ & $\begin{array}{l}\text { The trace } \\
\text { and } \\
\text { recording } \\
\text { in apps; } \\
\mathrm{U} \text { disk }\end{array}$ & $\begin{array}{l}\text { Record and } \\
\text { trace } \\
\text { activities }\end{array}$ & $\begin{array}{l}\text { To enhance } \\
\text { self-cognition }\end{array}$ \\
\hline
\end{tabular}




\section{Preparation before Class-Students Dominate}

Wisdom teaching aims to make an improvement in students' ways of learning and autonomic learning. Teachers should show scientific and appropriate ways of learning, so that students can choose and use proper means in different learning statues to learn effectively.

In flipped spoken English classroom, teachers assign what they will learn and ask students to finish it before class. Students learn the relevant expressions, skills and cultural background via micro-course and MOOC videos. They can perfect their pronunciation via Fluent English app after choosing some relevant courses in it and practice them until they get satisfied scores. In this way students can perform better in class, and learn automatically with good preparation.

In the procedure, the teaching videos can be found online or made by teachers. When making by themselves, teachers need to pay attention to the details of the microcourses, put forward proper micro questions and offer interactions to provoke students to think, hence clarifying teaching objectives and deepening students understanding. The oral material should meet the needs of job hunting, overseas traveling and studying abroad on the one hand, and in correspond with the interests and thoughts of new college students on the other hand. Daily dialogues, monologues and team debates are the three layers of micro-courses to cultivate students' oral competence.

Using Fluent English app is an embodiment of mobile micro-learning. In 2011, Gerhard Rot, a famous European brain researcher, proved that the micro learning unit and frequent repetition are the best way of brain working from the perspective of neurology. [4] The small units in English oral communication are quite proper to be learned via mobile devices at anytime and anyplace, which is an informal but practical learning mode. [5] This app developed with voice testing and assessing, can feedback immediately and give correction. By practicing and challenging repeatedly, students would be stimulated to enjoy learning English. It can also keep learning records, so that teachers can know and check students' learning progress, guiding the teaching in turn.

\section{Demonstration and Interaction in Class-Teacher Guides, Students Dominate}

Wisdom teaching puts emphasis on the cultivation of students' initiative and tries to promote them to learn vigorously in a relaxed atmosphere. Students should be encouraged to found the chance of development and success, so that they can put more time and energy into learning. Variable ways of inquiry and exploration are advisable in teaching. Freedom to explore, discuss and express should be entitled to students.

The flipped spoken English classroom is no long a place to pass the knowledge, but a place to steer students to grasp the learning strategies and practice their oral English. The activities in it should be designed practically and applicably. Topic discussion - students choose the hot topic, search for the new words and expressions before the class, and then they express their opinions in class. When clashed views occur, teachers guide students to question, to supplement and finally to revise, in which students can share and understand others' opinions and knowledge better. Demonstration and illustration - with the given knowledge, students are required to illustrate or demonstrate what they had prepared before class about people, things and social events by multimedia or videos. Debate-for those sensitive and hot social issues, students can debate in groups, which is to foster their English way of thinking. Brief English speech-collect some meaningful and thought-provoking themes, students prepare the speech draft in advance, and give a speech in class, which is helpful to enhance their selfconfidence and the ability to express orally. Story tellingteacher begins a story, then students continue to tell with their imagination, making a whole one together, which is useful to broaden their thinking. Read aloud beautiful essay-after choosing a beautiful and meaningful essay, students learn the vocabulary and the text by themselves, listen and read aloud, which is favorable to nurture their language sense and sentiment.

In each activity, teachers need to pay attention to the bystanders. An assessment form and oral comments are advisable to evaluate their performance. Variable activities should be designed to encourage students to take part in as an innovative and liberal individual or team. Teachers should show their respect to the students, learn to appreciate their different and polynary opinions, encourage them to share feelings and views, stimulate them to find the problems and try to solve them with their knowledge and experience. Only in this teaching atmosphere can teachers better cultivate students' innovative and practical competence, as well as fostering their critical thinking.

\section{Consolidation and Practice after Class-Students Dominate}

Experience is the foundation of rational perception and thinking. It is a carrier of the conversion from rational knowledge to wisdom. Teaching not only passes on the rational language, but teaches students to learn, to apply and to create. Practice is a way to integrate the original knowledge and experience to form new ones.

In flipped class, spoken English situational lab is a good place to practice oral English in the absence of language environment, where students can perform lively with their acquired language skills. In addition, video making, reading training, dubbing exercise and English songs are all extracurricular activities used to consolidate and practice oral language and skills. The Chanter app and English Funny Dubbing app are modern means to achieve personalized learning. Teachers should make clear the requirements for each activity, including the contents, forms, objectives and assessments. Students work in groups to practice conversations, prepare for the decorations and making videos after class. When doing these, students learn to cooperate with others, exchange ideas and develop favorable relationship. Consequently, their knowledge, wisdom and thoughts are developed. 
Since practical activities are dynamic, teachers should not neglect supervising and directing. On the premise of autonomic learning and practicing, teacher should pay attention to project and arrange in advance, making the practical activities are under the rules and in correspond with teaching objectives.

\section{Feedback_-Teachers and Students Involved}

After each assignment and activity, teacher should learn about how the students behave and give feedback to them by means of files, homework, exams and mutual assessment. In turn, students can also know about their own study. According to the results of the evaluation, teacher should give group or individual tutoring so as to promote team cooperation and knowledge acquisition. Based on the feedback and teaching effects, teachers should make timely adjustment to the classroom activities and micro-course videos in order to optimize teaching materials. Due to the limited classroom time, the checking can be carried out online and offline. For example, except those demonstrate and comment in class, the other students who have no chance to engage can put their recording and videos online via smart phones or other devices. After commenting and checking online, teachers feedback the whole evaluation, including the strengths, shortcomings and problems to help students to construct new knowledge system. The speech drafts and the situational conversations can be checked online in PiGai website firstly. By correcting on their own, students can remember and reflect deeply. In the whole procedure, except for the records in apps, the electronic files are necessary to store the recordings, videos and assessment forms, by which students can evaluate their learning and set up new goals and expectations.

\section{CONCLUSION}

In traditional English speaking class, the teaching process outweighs the teaching effects and learning efficiency, while in the flipped classroom, it is reversed. The flipped mode fully integrates the autonomic learning after class and the interaction among students and between teachers and students, which is helpful to establish a favorable relationship. This harmonious relationship is beneficial for students to engage in class confidently and vigorously. Critical thinking can be cultivated by discussions and comments. Self-discipline, self-cognition and team work are enhanced by assignments and autonomic learning. Therefore, students' wisdom thinking and competence are promoted in many aspects. The challenges that teachers confront in flipped classroom are the technology of making videos, the difficulties of encouraging autonomic learning, the ways of evaluating teaching effects and learning efficiency. In the meanwhile, teachers should pay attention to coordinate the traditional class with modern teaching methods in order to remain active influence of students' thoughts, emotions and characters.

\section{REFERENCES}

[1] A.N. Whitehead, $\mathrm{Xu}$ Ruzhou translated. The Purposes of Education[M]. Joint Publishing Press, 2002.

[2] R.J. Sternberg, Wu Gohong, Qinwen translated. Educate for Wisdom Students[M]. East China Normal University Press, 1999.

[3] Chen Jing. Wisdom Teaching Mode from Whitehead's Teaching Theory[J]. Journal of Teaching and Management, 2014,(6).

[4] Oberg A, Daniels P. Analysis of the Effect a Student-centered Mobile Learning Instructional Method has on Language Acquisition[J]. Computer Assisted Language Learning, 2013, (26):177-196

[5] Pan Yueming, Wang Changyu. Flipped Classroom Teaching Mode: from Theory to Practice-Based on the Popular Spoken English[J].Journal of Zhejiang Sci-Tech University (Social Science), 2014,(5).

[6] Chen Lisi, Wang Yaohui. A Study of English Vocabulary Memorizing from the Perspective of Mobile Micro-learning[J]. Modern Educational Technology, 2012,(9).

[7] Dai Hongbin. A Design of the Teaching Procedure and Interaction System in Flipped Classroom[J]. The Chinese Journal of ICT in Education, 2016,(11).

[8] Liu Yating. A Feasibility Study of Extracurricular Portfolios in College Spoken English[D]. Central China Normal University, 2015.

[9] Miao Li.The Instructional Design of Micro-lecture Based on Flipped Classroom in College English Speaking Class[J].Journal of Beijing City University, 2015, (4).

[10] Wei Jiaqi. An Overview of the Studies in China about English Learning[J]. Journal of Jilin TV Radio University, 2012,(11).

[11] Wang Xiaodong, Yu Na. The Principles and Ways to Design the Extracurricular Activities in College Spoken English[J]. Journal of North East Agriculture University(Social Science), 2007, (4).

[12] Wang Lili. A Study on the Teaching Reform and Development of College English in Internet Plus Era[J]. Heilongjiang Researches on Higher Education, 2015,(8)

[13] Yan Yudan. College English Extracurricular Cooperative LearningA Study on Oral Cooperation[J]. Journal of Higher Education, 2015, (4).

[14] Zhu Xun. A Study of Extracurricular Supervision Mechanism in College Spoken English[J].Foreign Language World, 2005, (8).

[15] Zheng Weiyong. A Mobile Micro Design of English Vocabulary Learning System[J]. Laboratory Research and Explore, 2014, (3).

[16] Zhou Yun. An Application Study of Videos and Micro Blog on Extracurricular Training in College Spoken English[J]. Modern Educational Technology, 2013,(5). 